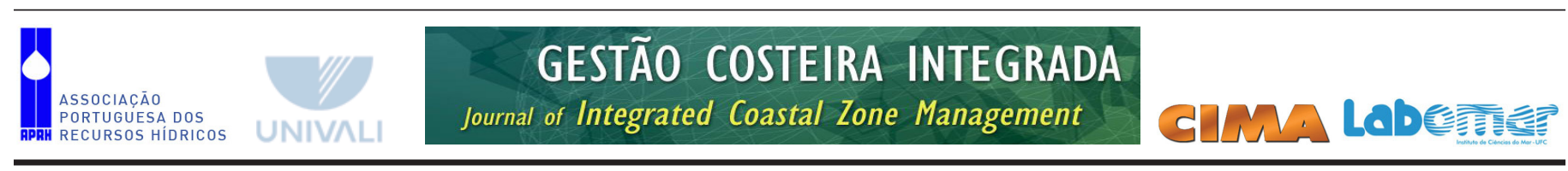

http://www.aprh.pt/rgci/pdf/rgci-496_Calado.pdf | DOI:10.5894/rgci496

\title{
Developing a Planning and Management System for Protected Areas on Small Islands (The Azores Archipelago, Portugal): the SMARTPARKS Project *
}

\author{
Desenvolvimento de um Sistema Integrado de Planeamento e Gestão de Áreas \\ Protegidas em Pequenas Ilhas Oceânicas (Arquipélago dos Açores, Portugal): \\ o Projecto SMARTPARKS
}

\author{
Helena Calado ${ }^{\circledR, 1}$, Marta Vergílio ${ }^{1}$, Catarina Fonseca ${ }^{2}$, Artur Gil ${ }^{3}$, Fabiana Moniz ${ }^{1}$, Susana Ferreira Silva ${ }^{1}$, \\ Miguel Moreira ${ }^{1}$, Chiara Bragagnolo ${ }^{4}$, Carlos Silva ${ }^{2}$, Margarida Pereira ${ }^{2}$
}

\section{ABSTRACT}

Small Islands face particular challenges in their sustainable development, and therefore require specific tailored approaches for planning and management. Unsurprisingly, protected areas have a special role in the conservation of biodiversity and natural resources crucial to the sustainability of such territories. How should the management and planning system of protected areas in small islands be, therefore, structured and operated so it can face the threats and challenges falling upon the already fragile and vulnerable insular ecosystems? This is the central question of SMARTPARKS Project. The core objective of the project consists of the conceptual development of a planning and management system for protected areas that can be integrated with the territorial management instruments in force, and that takes into consideration the specificities of insular ecosystems, correcting or perfecting the insufficiencies or flaws already pointed out to traditional planning systems of protected areas. This paper presents the SMARTPARKS Project, its rationale and main outcomes. Taking Pico Island Natural Park (Azores, Portugal) as its case study, the SMARTPARKS Project has adopted the ecosystem approach and the conciliation of conservation objectives with human needs and activities. Throughout its five tasks several studies were developed, and contributed to the functional analysis (developed during the last task) of each protected area constituting the Island Natural Park, in terms of their conservation and development values. This innovative application allows not only an integrated assessment of the protected areas but also a sustained monitoring.

Keywords: Small Islands; Island Natural Park; Planning; Management; Azores.

\section{@- Corresponding author:}

1 - CIBIO - Research Centre in Biodiversity and Genetics Resources, Department of Biology/Geography Section, University of the Azores, Rua da Mãe de Deus, Apartado 1422,9500-855 Ponta Delgada,Portugal calado@uac.pt, geografia@uac.pt; miguelmoreira@uac.pt; susana.silva@uac.pt

2 - e-Geo - Centro de Estudos de Geografia e Planeamento Regional. Faculdade de Ciências Sociais e Humanas, Universidade NOVA de Lisboa, Avenida de Berma 26C,1069-050 Portugal cps@fcsh.unl.pt; ma.pereira@fcsh.unl.pt; catarinafonseca7@gmail.com.

3 - Azorean Biodiversity Group, CITA-A, Department of Biology, University of the Azores, Rua da Mãe de Deus 13A, 9501-801 Ponta Delgada, Portugal arturgil@uac.pt 4 - Institute of Biological and Health Sciences, Federal University of Alagoas (UFAL) Av. Lourival Melo Mota, s/n, Tabuleiro do Martins, Maceió, AL 57072900,Brazil chiara.bragagnolo@yahoo.com.br 


\section{RESUMO}

As pequenas ilhas oceânicas enfrentam desafios particulares com vista ao seu desenvolvimento sustentável, necessitando consequentemente de abordagens técnicas de base cientifica especificas no desenvolvimento das suas estratégias de planeamento e gestâo territoriais. É inquestionável a relevância do papel das áreas protegidas quer na conservaçāo da biodiversidade e dos recursos naturais, quer na sustentabilidade dos territórios por elas abrangidos. De que modo deve ser então definido o modelo de planeamento e gestão de áreas protegidas em pequenas ilhas oceânicas para poder fazer face a todas as ameaças e desafios com que se deparam estes frágeis e vulneráveis ecossistemas costeiros? Esta é a questäo principal pela qual se rege o projecto SMARTPARKS. O objectivo nuclear deste projecto consiste no desenvolvimento conceptual de um sistema integrado de planeamento e gestão de áreas protegidas que possa integrar, complementar e fortalecer os instrumentos de gestão territorial vigentes, e que tenha em consideração as particularidades e especificidades destes ecossistemas insulares, corrigindo ou minimizando as falhas e insuficiências já identificadas das ferramentas e técnicas tradicionais de planeamento territorial de áreas protegidas. Este artigo apresenta o projecto SMARTPARKS, o seu contexto, a sua abordagem conceptual e os seus principais resultados. O Parque Natural de Ilha do Pico (Arquipélago dos Açores, Portugal) constitui o caso de estudo deste projecto, estando o desenvolvimento conceptual do SMARTPARKS especialmente focado numa sinergia definida pela abordagem ecossistémica e pela sua tentativa de conciliação com os objectivos de conservação com todas as necessidades e actividades humanas de cariz sócio-económico e cultural desenvolvidas no território abrangido. Ao longo do seu desenvolvimento metodológico dividido em 5 grandes tarefas, vários estudos especificos foram realizados, contribuindo nomeadamente para a análise funcional (em termos de valores para a conservação e desenvolvimento) que foi feita para cada área protegida que compóe o Parque Natural de Ilha do Pico. Esta abordagem metodológica inovadora permite não só uma avaliação integrada das áreas protegidas como também a sua monitorização sustentável.

Palavras-chave: Pequenas ilhas oceânicas; Parque Natural de Ilha; Planeamento; Gestão; Açores.

\section{INTRODUCTION}

Small islands are ipso facto largely coastal entities (Saffache \& Angelelli, 2010). Island ecosystems are inherently vulnerable systems, and anthropogenic pressures, such as land use changes, are one of the main threats to its biodiversity conservation (Lagabrielle et al., 2009). Islands vulnerability (Rietbergen et al., 2007) associated with remoteness, isolation, smallness, and closed systems represent an additional challenge in scientific and technical terms for Planning and Management on small islands (Calado et al., 2007; Calado et al., 2013), including the SIDS (Small Island Developing States) and Ultra-Peripheral European Regions (UPER), such as the Azores archipelago in Portugal (Gil et al., 2011; Gil et al., 2012).

Protected areas (PA) are the basis of local, regional, and global strategies for the conservation of biodiversity (Gaston et al., 2008; EEA, 2012). Conservation can be traced back almost as far as recorded history, however public awareness and the development of organizations to implement it has taken place within the last century (Green, 1996).

The concepts of conservation and protected areas have evolved significantly over time, reflecting the rules, attitudes and values of each generation (Mulongoy \& Chape, 2004; Ervin et al., 2010). First areas intended for conservation were in fact deemed to have significance for spiritual and religious reasons, and later when land was set aside for hunting reserves (EEA, 2012).

Conservation as we know it nowadays was only generally recognized in the latter half of the 19th century. The first real protected areas were declared in Germany in the 1820s (EEA, 2012) and the first "National Park" been created was the Yellowstone National Park in the United States in 1872 (Mulongoy \& Chape, 2004). At that time protected areas were almost free of human influence, and were managed mainly for visitors and tourists, placing high value on wilderness and natural sceneries with little regard for the local communities (Phillips, 2003a). Societal benefits were mostly considered as incompatible with protected area objectives, compromising nature conservation and landscape protection (EEA, 2012).

During the Second World Conference on National Parks (held in 1972, in Yellowstone and Grand Teton national parks, USA) were adopted recommendations on what were the priorities for protected areas. Phillips (2003a) highlights the failure to address the connections between protected areas and questions of development in general, and between protected areas and the areas around them in particular.

However, by the 1970s, planners of protected areas began to acknowledge the importance of local communities, and started to address the need for more systematically and comprehensively designed networks of protected areas. Protected areas began to be viewed more as social enterprises to be managed also accordingly to the needs of local communities (EEA, 2012).

Currently, more than just protection of biodiversity is expected from protected areas. They are viewed as a critical component of a life support system, as nodes of environmental resilience, and a source of ecosystem services (EEA, 2012). And it is currently recognized that several ecosystems, some of them humanized, have high value and whose conservation depends on appropriated and/or human-induced management actions (Ervin et al., 2010; Cruz et al.,, 2011).

Considering the specificities of islands, it is even more important to integrate both perspectives of conservation and development, and find a balance between objectives of both, especially in small islands. The small size and well defined boundaries difficult the connections with other territories, whether they are key connections for biodiversity preservation or key connections for human activities development. Mainland Planning Systems rely on these connections to face constraints and shortcomings. Islands Planning Systems don't have that choice.

These tremendous challenges faced by Small Islands Protected Areas demand the highest possible levels of strategy, planning and activity programming. They further necessitate that managers proceed with the utmost transparency and 
rigor while sharing the responsibility of management in the search for the optimal utilization of human, technical, technological and financial resources of each of the strategic stakeholders (Gil et al., 2011).

In order to ensure maximum effectiveness, and accomplish conservation and sustainable development objectives, planning and management systems of protected areas need to be adjusted to the specific context of small islands (Fonseca et al., 2011). In what way should this adjustment be structured and operated is the central question of the SMARTPARKS Project.

The main objective of the SMARTPARKS Project - "Planning and Management System for Small Islands Protected Areas" was, therefore, the conceptual development of a planning and management system for protected areas in small islands. This system should consider the specificities of islands ecosystems, correcting and improving the insufficiencies and gaps of traditional planning systems. Moreover, it should be able to be integrated in the territorial management instruments in force and to be applied in other islands or archipelagos, but especially in small islands.

This article intends to present the SMARTPARKS Project, its rationale and main outcomes in order to contribute to management systems of protected areas in the Azores, as well as other small islands.

The SMARTPARKS Project (PTDC/AACAMB/098786/2008) was funded by the Fundação para a Ciência e a Tecnologia (FCT). The Project is already finished and is under final procedures from FCT. Although the Project is finished, its implementation in Pico Island depends on Regional Government Agencies, as well as the Natural Park Administration.

\section{DEVELOPMENT OF THE SMARTPARKS PROJECT}

\subsection{Rationale of the SMARTPARKS}

The rationale of the SMARTPARKS Project relies mainly on two approaches (Fonseca et al., 2011): the so called "new paradigm" (Phillips, 2003b) of protected areas' classification, planning and management to the insular ecosystems' specificities, and the ecosystem approach (SCBD, 2004). That "new paradigm" focuses on the compatibility of conservation and human activities, and explicitly considers that human communities are part of ecosystems. This new perspective allows the emergence of new economic and cultural development opportunities within protected areas, such as ecotourism, integration of protected areas in conservation networks, their integration in territorial management systems, and the involvement of locals and stakeholders in achieving protected areas' objectives. The ecosystem approach considers the protected area as an integrating part not dissociable from the island's ecological structure and biophysical system (Vieira, 2007), reflecting the effects that planning policies and territorial management measures may have in the entire island. The combination of these approaches extends beyond the conservation strategy focused only on the protection of species or on the management of areas, habitats or hotspots. It integrates environmental components, as well as socio- economic, contributing to the sustainable development of the protected area and, ultimately, of the island as a whole (Fonseca et al., 2011).

The Project developed its own mnemonic for the acronym "SMART" which tries to translate what is intended with this Project (Figure 1).

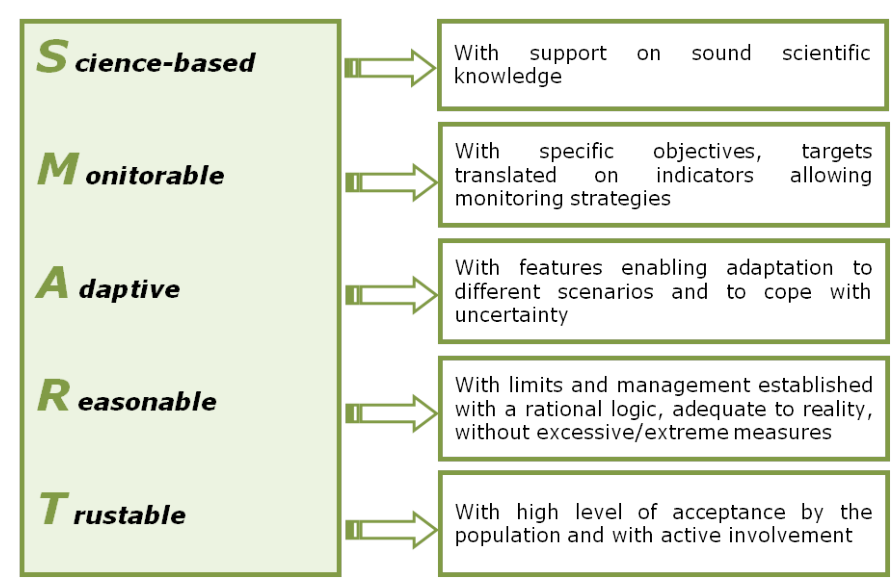

Figure 1. SMART Protected Areas mnemonic. Figura 1. Mnemónica de Áreas Protegidas "SMART".

The development of the SMARTPARKS Project was based on the study, conception and methodological development of each of the following 5 tasks (which will be described below) for Island Parks:

(1) Island Park's Characterization, Assessment and Diagnosis;

(2) Island Park's Ecosystems Services Assessment and Valuation;

(3) Island Park's Land Planning;

(4) Island Park's Management and Monitoring Strategies;

(5) Environmental Strategic Assessment of Island Park's Planning and Management System.

The various studies conducted on each task were applied and validated in Pico Island (the Azores, Portugal), chosen as the case study of the project.

Considering the basis of the Project and its objectives, Pico Island Park was chosen due to its percentage of classified area and diversity, and representativeness of protection categories. Pico Island Park is emblematic at the regional and national scale, not only due to its natural and ecological values but also due to the balance between nature and human use, well exemplified by the landscape of the Pico Island vineyards culture, a UNESCO World Heritage Site.

Due to its political and administrative autonomy from Portugal mainland, the Azorean Regional Government has authority to adapt national legislation to regional specific needs. The Azorean Government recognizes the importance of preserving the natural resources, as well as to accomplish with the international commitments undersigned by the 
Portuguese Republic, and proceeded to the re-classification of its Protected Areas Network (Calado et al., 2009). That re-classification complies with the IUCN Category System. In the Azores, this conceptual classification model is based on management criteria for each area. The competences to do it are concentrated in one management structure for each island (Calado et al., 2009). This led to the creation of an Island Natural Park for each island, which comprises all the classification categories and considers the entire island as a territorial base unit for management (where each island's assemblage of PA represents an Island Natural Park).

\subsection{The Azores Archipelago and Pico Island}

The Azores Archipelago comprises nine volcanic islands distributed along $600 \mathrm{~km}$ in the middle of the North Atlantic, circa $1500 \mathrm{~km}$ from Lisbon and $3900 \mathrm{~km}$ from the east coast of North America. The islands are divided into three groups: the Western Group (Flores and Corvo), the Central Group (Pico, Faial, São Jorge, Graciosa and Terceira) and the Eastern Group (São Miguel and Santa Maria) (Figure 2).

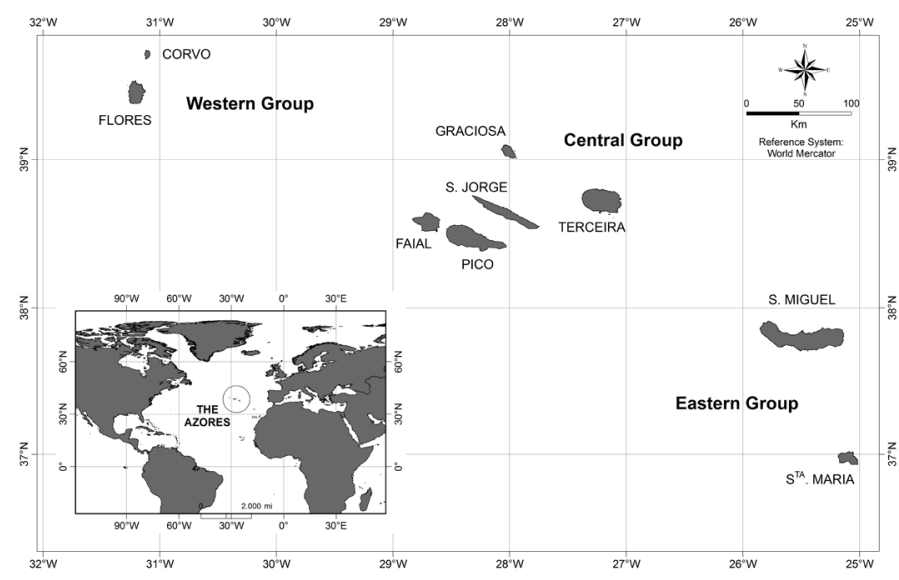

Figure 2. Azores archipelago.

Figure 2. Arquipélago dos Açores.

Along with Madeira archipelago (Portugal), Canary Islands (Spain) and Cape Verde, the Azores are part of the biogeographically region of Macaronesia, one of Europe's richest in terms of fungi, plants and animals. This ecoregion presents exceptional plant, animal and ecosystem endemisms (Petit \& Prudent, 2010), namely associated with its typical Laurel forest, and high levels of vulnerability (Cardoso et al., 2008).

The Azores is close to the triple junction of the American, Eurasian and African plates, and is subject to intense seismic activity (Cruz, 2003). Its exposed northern mid-Atlantic location, morphology and plate-tectonics setting make the Azores highly vulnerable to natural hazards, such as tsunamis associated with landslides and seismic or volcanic triggers (Andrade et al., 2006).
Pico Island is the second largest and most recently formed island of the archipelago (Cruz \& Silva, 2000), with $447 \mathrm{~km}^{2}$ area and $151.8 \mathrm{~km}$ perimeter, between coordinates $38^{\circ} 22^{\prime} 57^{\prime \prime}$ and $38^{\circ} 33^{\prime} 44^{\prime \prime} \mathrm{N}$ and $28^{\circ} 01^{\prime} 39^{\prime \prime}$ and $28^{\circ} 32^{\prime} 33^{\prime \prime} \mathrm{W}$ (SRAM, 2008). It is regionally known as the "Mountain Island" due to its most striking feature: a volcanic mountain (Figure3), the highest mountain in Portugal, reaching an altitude of $2351 \mathrm{~m}$.

Pico's climate is classified as marine temperate (Cruz, 2003). This fact together with the island small size contributes to a small diversity of water resources and to watersheds of little dimension (usually less than $\left.30 \mathrm{~km}^{2}\right)$ (DROTRH/IA, 2001).

Pico Island is divided into three municipalities: São Roque do Pico, Madalena, and Lajes do Pico. This is essentially a rural territory with a population density of approximately $32.8 \mathrm{inhab} / \mathrm{km}^{2}$ (SREA, 2010). Similarly to the other Azorean islands, its geological, geomorphologic and climatic constraints, as well as its dependence on the sea as the most important communication route, are mainly responsible for the location of settlements, human activities and transportation infrastructures along the coastline (Porteiro et al., 2005).

The current economy of the Archipelago is mainly based on a small domestic market, dependent on agriculture, cattle grazing, tourism and fisheries. Manufacturing relies mostly on primary products (mainly livestock, dairy and fish) and tourism is currently increasing both in terms of supply and demand.

The coastal zone of Pico is essentially covered by urban and agricultural areas, including the traditional viticulture area. The middle ring of the island is mostly covered by pasture mixed with semi-natural vegetation and significant presence of invasive and non-indigenous species. Higher areas are predominantly covered by pasture mixed with natural areas and a significant presence of endemic species.

Pico Island Natural Park includes 19 terrestrial protected areas and 3 marine protected areas. It is the largest Natural Park of the Azores comprising $156 \mathrm{~km}^{2}$ of terrestrial surface, around $35 \%$ of the island territory, and $79 \mathrm{~km}^{2}$ of marine area. Of its 22 protected areas, 4 are classified as nature reserve, 1 as natural monument, 8 as protected area for species/habitats management (mainly coastal areas), 6 as protected landscape and 3 as protected area for resources management (all marine areas) (Figure 3).

\subsection{Tasks and Main Outcomes}

\section{Task 1. Island Park's Characterization, Assessment and Diagnostic}

In this task the aim was to develop a new diagnosis and characterization strategy for the Island Park, based on the collection, study and analysis of existing methodologies for characterization, mapping and evaluation of protected areas in islands. To achieve that, some studies were performed and their outcomes used as inputs in the following tasks.

\section{Summary Tables:}

- Setting specific objectives: Area of Pico Island Park.

- Preliminary analysis of the reasons for the classification, 


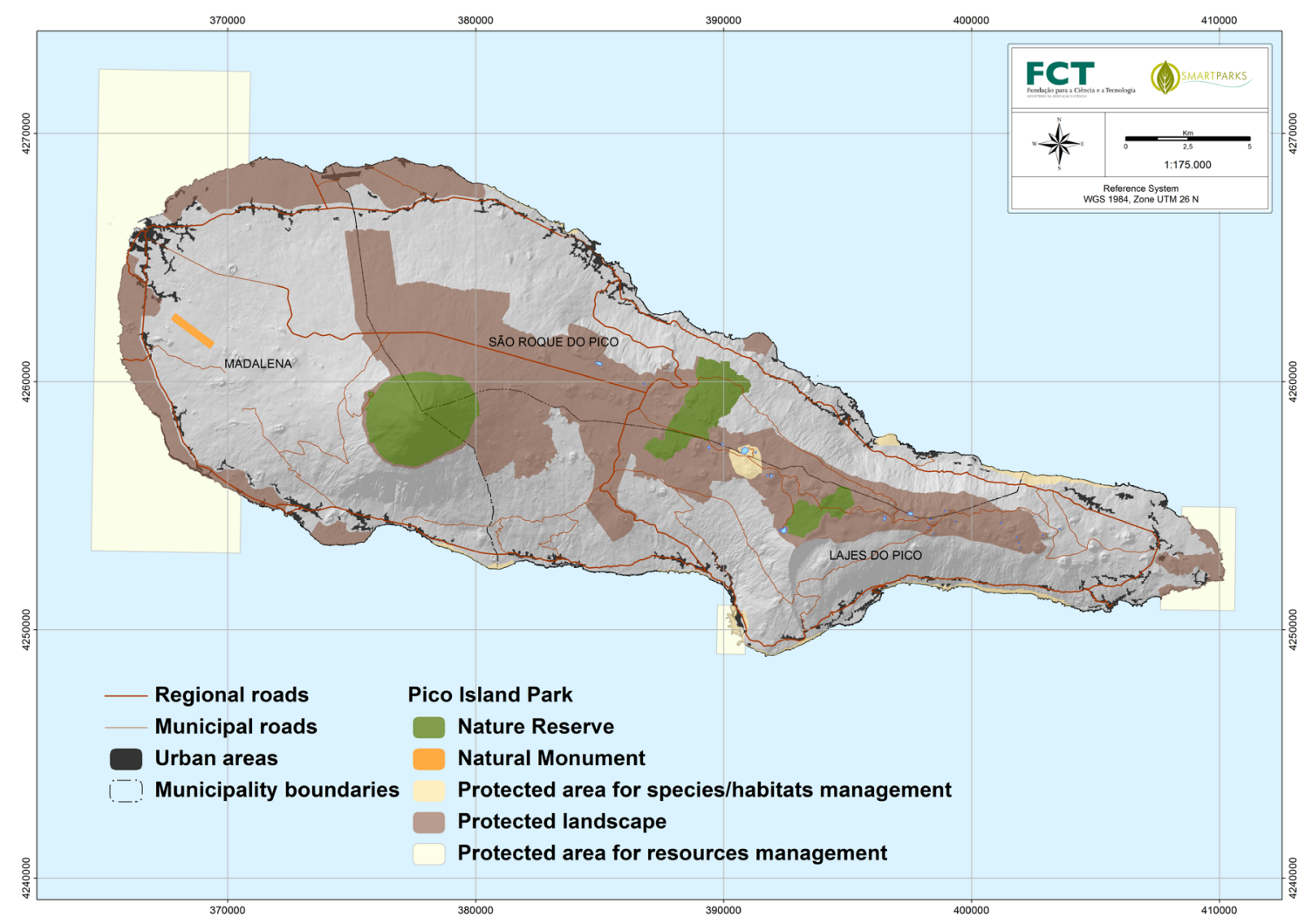

Figure 3. Pico Island Park (adapted from data provided by Direcção Regional do Ambiente dos Açores). Figura 3. Parque Natural de Ilha do Pico (adaptado de informação cedida pela Direcção Regional do Ambiente dos Açores).

objectives and interdictions in the Protected Area of Pico Island Park.

- Characterization of the Natura 2000 Network on the Pico Island.

The main objectives of these studies were to develop a starting point and an overview of the current situation of Protected Areas included in the Island Park. Identifying gaps and trends allows developing a more suitable proposal of the planning and management system.

\section{Technical Reports:}

- Preliminary Coastal Vulnerability Assessment for Pico Island - the aim of this report was a preliminary analysis of the level of coastal vulnerability according to the Delphi method, in which 14 sites were observed considering the interactions between coastal dynamics, natural environment and developed anthropogenic activities.

- Land Cover Map of Pico Island 2008 through Photointerpretation - the main objective was to identify the main classes of land use on Pico Island and its Natural Park, weaving comparisons between them. This study also provided a base map that was available to other team members in order to develop work that needed mapping of occupation and land use.

- Relevant data and information for a comprehensive conservation planning in Small Islands - this study incorporates an analysis of the mapping data produced and adapted to the level required by the biophysical component (type of habitats, ecosystems, species richness and endemics entities, main pressures on the island biodiversity), anthropogenic (human history influences) and legislative (conservation policies with special attention to the concept of "Island Natural Park") for the entire Pico island.

- Assessment of Pico Island Park Biodiversity through the InVEST methodology - the main objective was the valuation of habitats and the identification of priority areas in terms of recovery and conservation, through the analysis of the quality of habitats and the level of degradation of these.

- Update of the Land Use Map 2013 - in applying the InVEST Biodiversity methodology a field work campaign was undertaken between September 1-6, 2013, to support the update of the Land Use Cartography. Its specific objectives were: (i) to define the study areas and to discuss the INVEST methodology through meetings with local technicians and experts from the Pico Island Natural Park and the Regional Directorate for Nature Conservation (DRCN); (ii) to validate and update the Land Use Map (v.2008) by obtaining GPS points for the classes in question (groundtruth), focusing on areas of bogs, and by identifying studied species and their respective habitats.

- Analysis and Evaluation of Pico Landscape - identification of main landscape values and weaknesses of protected 
areas of lower and higher altitude, based on field work and on the results of surveys to the resident population and tourists.

- Analysis of the relationship between Pico Island Park and the Geopark - this study concluded that most of Pico geosites (priority or not) totally or partially match with areas of the Natural Park.

- Pico Island Socioeconomic Characterization - a key component of the project focused on the social and economic analysis of the Pico Island, in order to integrate both conservation and development approaches.

- Public Participation in Pico Island - Tourists Survey this study aimed to gather information regarding the perceptions and expectations of the resident population and visitors to the Pico Island protected areas.

- Territorial Conflicts in Small Island Protected Areas: the case of Pico Island, Azores - Portugal - the main objectives of this analysis were: (i) identification of the background for conflicts emergence; (ii) characterization of the types of territorial conflicts; (iii) identification of conflicts locations; (iv) identification of the problems derived from the main instruments of spatial planning targeted towards nature conservation objectives; and (v) location of existing and potential territorial conflicts in the volcanic islands spatial organization model.

- Validation Proposal of the Pico Island Park Areas contribution of predictive species distribution models - this study was developed in order to diagnose the probability of occurrence of the most relevant species in a conservationist point of view, subsequently evaluating if the areas of higher probability are within the limits of the Pico Island Park. This study supported the study on the valuation of biodiversity and also allowed to some considerations regarding areas potentially important for protected species outside protected areas.

\section{Task 2. Island Park's Ecosystems Services Assessment}

Task 2 was designed to propose a new strategy for the Island Park's ecoservices assessment and valuation, based on the collection, study and analysis of existing methodologies for economic assessment and ecoservices valuation. This approach was intended to promote public awareness and participation and to support cost-benefit analysis of planning policies and management measures. Different studies were developed under this task.

\section{Technical Reports:}

- Economic Valuation - analysis tools - literature review exploring the different categories of values and methodologies available for their assessment and quantification.

- Multitemporal Analysis of the Environmental Value of Pico Island Natural Ecosystems - this study aimed to contribute to the analysis of the ecosystems economic valuation. It was carried out through: (i) analysis of land uses available in four different time periods (1999, 2005, 2007, and 2009); (ii) identification of land use modifications between these periods; (iii) correspondence between land use types found in the classification of the Pico Forest Inventory, GlobeCover and Corine Land Cover, and ecosystems identified by Costanza et al. (1998); (iv) estimate the economic value of natural ecosystems and land uses for these periods based on the values identified. This allowed the economic valuation of gains and losses resulting from land use changes.

Ecosystem Function Identification and Spatialization in Pico Island - identification and spatialization of the major groups of ecosystem functions and analysis of whether or not the current boundaries of the protected areas correspond to the location of such functions.

\section{Task 3. Island Park's Land Planning}

The information produced during the previous tasks was integrated and the need of a new territorial planning strategy for the Island Natural Park was assessed, taking into consideration the existing Planning Instruments and their legal framework under the Portuguese legal Framework.

\section{Technical Reports:}

- Pico Island Ecological Reserve - Analysis of the application of the National Ecological Reserve (NER) in the insular context of Azores Autonomous Region. This study was applied to Pico Island, integrating zoning and conflict analysis. The result was a proposal for delimitation of NER in the island.

- Island Ecological Structure: Pico Island - the aim of this study was to propose a network of green and natural spaces contributing to preserve values and functions of natural ecosystems that provide benefits to society. This ecological structure intends to contribute to harmonize local communities and the conservation of natural systems on which they depend.

\section{Internship Report:}

- Contribution of Territorial Management Instruments (TMI) for the Sustainability of Pico Island Park - this work comprised the following objectives: (i) to identify TMI in force on the Pico island; (ii) to identify the scope and specific objectives of each TMI; (iii) to identify overlapping between the intervention area of each instrument and the Natural Park; (iv) to evaluate the adequacy/compatibility between the ITM resolutions and the protected areas' management objectives.

\section{Task 4. Island Park's Management and Monitoring}

In order to be able to design future monitoring programs it is necessary to understand the relationship between different scales and spaces. Therefore in this task a major theoretical discussion about this issue was produced in a technical report.

\section{Technical Report:}

- A multi - scale approach to conservation planning in Small Island Archipelagos: The Azores - this study suggests that planning and management in small islands are tested in three scales. The first, at the archipelago level, comprises 
the analysis regarding the weight of insularity and the limitations and implications for management. The second, at the level of the island groups (Eastern, Central and Western), analyzes the strengths and weaknesses of connectivity between islands of the same group (internal connectivity) and between groups (external connectivity), as well as the resulting environmental and socioeconomic impacts and potential vulnerabilities. And the third, at the island scale, with the case study of Pico Island, with the proposal to apply the model of "volcanic islands" as the basis for monitoring actions and measures implemented.

\section{Task 5. Environmental Strategic Assessment of Island Park's Planning and Management System}

In this final task a proposal for the Strategic Environmental Assessment (SEA) of the Island Park's Planning and Management System was designed, introducing a new tool in SEA, the Functional Analysis.

\section{Technical Report:}

- Functional Analysis and Strategic Environmental Assessment of the Pico Island Park - Functional Analysis method (adapted from Cendero \& Fischer, 1997) is able to integrate all the information produced during the Project and provide valuable directions for management and decision-making. It identifies a series of characteristics which can be used to describe environmental, as well as socio-economic, components using different indicators. Numerical indices can be used to assess different qualities on the basis of these indicators. A "conservation versus development" diagram (such as Figure 4) is used as a tool to help identify and assess planning conflicts. This diagram is also an easy way to visualize and to help determine if environmental quality in a particular area is decreasing or increasing and, consequently, if the existing management and policy trends are moving away or towards sustainability.

The main objective of this analysis was to evaluate each area of the Natural Park, in terms of its potential for both conservation and development objectives (since most areas have direct and indirect use by residents and tourists, as demonstrated by the studies on the previous tasks).

Figure 4 exemplifies the diagram produced during the Functional Analysis, here applied to the 22 protected areas comprised in Pico Natural Park. Each protected area is identified in the diagram with a number ${ }^{1}$. The

1 - 1-Nature Reserve of Montanha do Pico; 2-Nature Reserve of Caveiro; 3-Nature Reserve of Mistério da Prainha; 4-Nature Reserve of Furnas de Santo António; 5-Natural Monument of Gruta das Torres; 6-Protected area for species/habitats management of Lagoa do Caiado; 7-Protected area for species/habitats management of Lajes do Pico; 8-Protected area for species/habitats management das Furnas de Santo António; 9-Protected area for species/habitats management of Silveira; 10-Protected area for species/habitats management of Mistério de São João; 11-Protected area for species/habitats management da Terra Alta; 12-Protected area for species/habitats management of Ribeiras; 13-Protected area for species/ habitats management of Zona do Morro; 14-Protected landscape of $\mathrm{x}$-axis and the $\mathrm{y}$-axis represent respectively the status of potential for development and conservation value. When both statuses have low values the protected area is under low conflicts. When both statuses have high values the protected area is under high conflicts between development and conservation objectives.

Through this tool, the several protected areas were evaluated and compared in terms of their potential for development and of their conservation value (Figure 4), considering ecological (e.g. conservation status and pressures on protected areas, water and climate regulation) and socioeconomic (e.g. goods and benefits from primary sectors, tourism and recreation) parameters properly weighted according to their importance for the objectives of conservation and/or development.

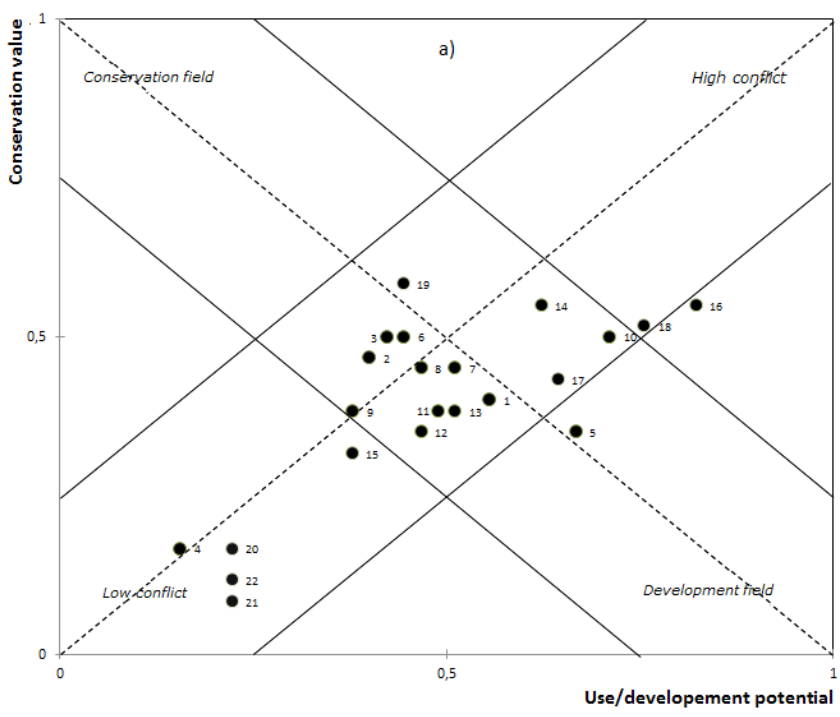

Figure 4. Functional Analysis for Pico Protected Areas.

Figura 4. Análise functional das Areas Protegidas do Pico.

\section{DISCUSSION AND CONCLUSION}

The SMARTPARKS Project attempted the conceptual development of a planning and management system for protected areas in small islands, integrating nature conservation and human activities, as well as a sound balance between them.

This project allowed an extensive information collection about Pico Island. This will be useful also for further studies in the island.

Cultura da Vinha - Ponta da Ilha; 15-Protected landscape of Cultura da Vinha - Ponta do Mistério; 16-Protected landscape of Cultura da Vinha - Zona Norte; 17-Protected landscape of Cultura da Vinha - São Mateus/ São Caetano; 18-Protected landscape of Cultura da Vinha - Zona Oeste; 19-Protected landscape of Cultura da Vinha of Central Zone; 20-Protected area for resources management of Porto das Lajes; 21-Protected area for resources management of Ponta da Ilha; 22-Protected area for resources management of Faial-Pico channel. 
Each developed task came out with interesting reports, some of them with new questions and opportunities for further research studies.

One of the major outcomes of the Project was the Functional Analysis tool applied to Protected Areas management, developed during Task 5.

The functional analysis applied as a technique for monitoring the 22 protected areas of the Pico Island Natural Park, proved to be a versatile tool. Land Use and Planning Systems in Portugal and the Azores are based on "land laws" instruments and therefore presenting rigid and static rules. In this sense, Functional Analysis may help by providing a dynamic follow up in a rigid system.

Marine protected areas (identified in Figure 4 with the numbers 20,21, and 22) present low values for both conservation and development potential. This occurred because they lacked basic information for some indicators and a smaller number of indicators was used for these protected areas, resulting on their position in the "low conflict" area of the diagram. Future works on evaluation will determine this balance between conservation and development in protected areas by improving new basic information.

The SMARTPARKS Project shows the central need of multidisciplinarity and of joining scientific know-how with practical experience.

The innovative methodology developed by SMARTPARKS Project was based on several strategic assumptions that we consider being of core importance when planning and managing small islands protected areas:

- "Small Islands" are unique and particular ecosystems whose management requires specific approaches and methodologies;

- Association and integration of the planning and management of the Protected Areas Network into the planning and management of the whole island, following a predominantly ecosystem approach (CBD, 2004) that considers the Protected Area as intrinsic and inseparable part of the Island's Ecological Structure and its Biophysical System, reflecting the direct and indirect effects of the planning policies and territorial management measures applied to the entire island;

- Adoption of the so-called "new paradigm" (Phillips, 2003) that focuses on the compatibility of conservation and human activities, encouraging the development of new economic and cultural opportunities associated to the protected areas, their full integration in territorial management systems, and also the synergetic engagement of stakeholders and local population in achieving those same objectives;

- Reinforcement of protected areas' effectiveness regarding the associated nature conservation and biodiversity maintenance objectives, as well as the introduction of assessment methods for this effectiveness (Hockings et al., 2005) among which the "gap analysis" (Langhammer et al., 2007), by identifying their strengths, weaknesses, and solutions;

- Integration, within the planning policies and management measures to be implemented, of mitigation strategies and strategies to fight the greatest threats hanging over small island ecosystems (CBD, 2009): climate change and variability, proliferation of invasive exotic species, accelerated growth of touristic activity, natural catastrophes, overexploitation of natural resources, pollution and waste management;

- Integration of the "geodiversity" concept and the need to promote and ensure "geoconservation" in the planning and management policies of protected areas (Lima, 2007);

- Integration and promotion of public engagement in all stages of the Planning and Management System of Protected Areas on Small Islands;

- Integration of the economic assessment and valuation concept of services rendered by the ecosystems (ecoservices) to support the promotion of stakeholder involvement and public engagement, as well as to support the cost-benefit analysis regarding planning.

The outcomes of this Project, although valuable on future management and planning actions, should be validated by further application in the other Island Parks of the Azores. Also, a specific approach for marine/coastal areas should be tailored and built upon SMARTPARKS achievements.

\section{REFERENCES}

Andrade, C.; Borges, P.; Freitas, M.C. (2006) - Historical tsunami in the Azores archipelago (Portugal). Journal of Volcanology and Geothermal Research, 156(1-2):172-185. DOI: 10.1016/j.jvolgeores.2006.03.014

Calado, H.; Braga, A.; Moniz, F.; Gil, A.; Vergílio, M. (2013) - Spatial planning and resource use in the Azores. Mitigation and Adaptation Strategies for Global Change, First Published on-line in November 2013. DOI: 10.1007/s11027-013-9519-2

Calado, H.; Lopes, C.; Porteiro, J.; Paramio, L.; Monteiro, P. (2009) - Legal and Technical Framework of Azorean Protected Areas. Journal of Coastal Research (ISSN: 07490208), SI56:1179-1183. Available on-line at http:// www.jstor.org/stable/25737973

Calado, H.; Quintela, A.; Porteiro, J. (2007) - Integrated Coastal Zone Management Strategies on Small Islands. Journal of Coastal Research (ISSN: 0749-0208), SI50:125129, ICS2007 (Proceedings), Australia. Available on-line at http://www.redmic.es/bibliografia/Docum_03049.pdf

Cardoso, P.; Borges, P.A.V.; Costa, A.C.; Tristão da Cunha, R.; Gabriel, R.; Martins, A.M.F.; Silva, L.; Homem, N.; Martins, M.; Rodrigues, P.; Martins, B.; Mendonça, E. (2008) - A perspectiva arquipelágica: Açores. In: J. L. Martin; M. Arechavaleta; P. A. V. Borges; B. Faria (org.), Top 100. Las 100 especies amenazadas prioritarias de gestión en la región europea biogeográfica de la Macaronesia, pp. 421-449, Consejería de Medio Ambiente y Ordenación Territorial, Gobierno de Canarias, Spain. ISBN: 8489729387. Available on-line at https://repositorio. uac.pt/handle/10400.3/1962

Cendrero, A.; Fischer, D. (1997) - A Procedure for Assessing the Environment Quality of Coastal Areas for Planning 
and Management. Journal of Coastal Research (ISSN: 0749-0208), 13(3):732-744. Article Stable URL: http:// www.jstor.org/stable/4298668

Costanza, R.; d'Arge, R.; de Groot, R.; Farber, S.; Grasso, M.; Hannon, B.; Limburg, K.; Naeem, S.; O’Neill, R.V.; Paruelo, J.; Raskin, R.G.; Sutton, P.; van den Belt, M. (1998) - The value of the world's ecosystem services and natural capital. Ecological economics, 25(1):3-15. DOI: 10.1016/S0921-8009(98)00020-2

Cruz, A.; Benedicto, J.; Gil, A. (2011) - Socio-economic Benefits of Natura 2000 in Azores Islands - a Case Study approach on the ecosystem services provided by a Special Protected Area. Journal of Coastal Research (ISSN: 0749-0208), SI64:1955-1959, ICS2011 (Proceedings), Polonia. Available on-line at http://cita.angra.uac.pt/ ficheiros/publicacoes/1322865720.pdf

Cruz, J.V. (2003) - Groundwater and volcanoes: examples from the Azores archipelago. Environmental Geology, 44(3):343355. DOI: 10.1007/s00254-003-0769-2

Cruz, J.V.; Silva, M.O. (2000) - Groundwater salinization in Pico Island (Azores, Portugal): origin and mechanisms. Environmental Geology, 39(10):1181-1189. DOI: $10.1007 / \mathrm{s} 002540000109$

DROTRH; IA (2001) - Plano Regional da Água - Relatório Técnico - Versão para Consulta Pública. 414p., Ed. Secretaria Regional do Ambiente, Direcção Regional do Ordenamento do Território e dos Recursos Hídricos, Ponta Delgada, Portugal. Available on-line at http://portaldaagua.inag.pt/PT/InfoTecnica/PGA/ PRPlaneamento/Documents/relatorio_PRA.pdf

EEA (2012) - Protected Areas in Europe - an overview. 131 p., European Environment Agency, Copenhagen, Denmark. ISBN: ISBN: 978-9292133290. DOI: 10.2800/55955

Ervin, J.; Sekhran, N.; Dinu, A.; Gidda, S.; Vergeichik, M.; Mee, J. (2010) - Protected Areas for the 21 st Century: Lessons from UNDP/GEF's Portfolio. 132p., United Nations Development Programme, Montreal, Canada, Convention on Biological Diversity, New York, USA. ISBN: 9292252747. Available on-line at https://www. cbd.int/cms/ui/forums/attachment.aspx?id=89

Fonseca, C.; Calado, H.; Silva, C.P.; Gil, A. (2011) - New approaches to environment conservation and sustainability in small islands: the project SMARTPARKS. Journal of Coastal Research (ISSN: 0749-0208), SI64:1970-1974, ICS2011 (Proceedings), Poland. Available on-line at http://cita.angra.uac.pt/ ficheiros/publicacoes/1322869324.pdf

Gaston, K. J.; Jackson, S. F.; Cantú-Salazar, L.; CruzPiñón, G. (2008) - The Ecological Performance of Protected Areas. Annual Review of Ecology, Evolution, and Systematics, 39:93-113. DOI: 10.1146/annurev. ecolsys.39.110707.173529

Gil, A.; Fonseca, C.; Lobo, A.; Calado, H. (2012) - Linking GMES Space Component to the development of land policies in Outermost Regions - the Azores (Portugal) case-study. European Journal of Remote Sensing, 45:263281. DOI: $10.5721 / \mathrm{EuJRS20124524}$

Gil, A.; Calado, H.; Bentz, J. (2011) - Public participation in municipal transport planning processes - the case of the Sustainable Mobility Plan of Ponta Delgada, Azores,
Portugal. Journal of Transport Geography, 19(6):13091319. DOI: 10.1016/j.jtrangeo.2011.06.010

Gil, A.; Calado, H.; Costa, L.T.; Bentz, J.; Fonseca, C.; Lobo, A.; Vergilio, M.; Benedicto, J. (2011) - A Methodological Proposal for the Development of Natura 2000 Sites Management Plans. Journal of Coastal Research (ISSN: 0749-0208), SI64:1326-1330, ICS2011 (Proceedings), Poland. Available on-line at http://cita.angra.uac.pt/ ficheiros/publicacoes/1322869287.pdf

Green, B. (1996) - Countryside Conservation - Landscape ecology, planning and management (3rd Ed.). 359p., Spon, E \& FN, London, U.K.. ISBN: 0419218807

Hockings, M.; Stolton, S.; Leverington, F.; Dudley, N.; Courrau, J. (2006) - Evaluating Effectiveness: a framework for assessing management effectiveness of protected areas, 2nd edition. 105p., IUCN, Gland, Switzerland and Cambridge, UK. ISBN: 2-8317-0546-0. Available online at https://portals.iucn.org/library/efiles/edocs/PAG006.pdf

Lagabrielle, E.; Rouget, M.; Payet, K.; Wistebaar, N.; Durieux, L.; Baret, S.; Lombard, A.; Strasberg, D. (2009) - Identifying and mapping biodiversity processes for conservation planning in islands: A case study in Réunion Island (Western Indian Ocean). Biological Conservation, 142(7):1523-1535. DOI: 10.1016/j. biocon.2009.02.022

Langhammer, P.; Bakarr, M.; Bennun, L.; Brooks, T.; Clay, R.; Darwall, W.; Silva, N.; Edgar, G.; Eken, G.; Fishpool, L.; Fonseca, G.; Foster, M.; Knox, D.; Matiku, P.; Radford, E.; Rodrigues, A.; Salaman, P.; Sechrest, W.; Tordoff, A. (2007) - Identification and Gap Analysis of Key Biodiversity Areas: Targets for Comprehensive Protected Area Systems. 116p., IUCN, Gland, Switzerland. Available on-line at http://www.iucn.org/dbtw-wpd/edocs/PAG-015.pdf

Lima E.A. (2007) - Património Geológico dos Açores: valorização de locais com interesse geológico das áreas ambientais, contributo para o ordenamento do território. 108 p., MSc Thesis, Departamento de Biologia, Universidade dos Açores, Ponta Delgada, Portugal. Unpublished.

Mulongoy, K.J.; Chape, S. (2004) - Protected areas and biodiversity: An overview of key issues. 52p., CBD Secretariat, Montreal, Canada and UNEP-WCMC, Cambridge, UK. ISBN: 9280424045. Available on-line at https://archive.org/details/protectedareasbi04mulo

Petit, J.; Prudent, G. (2010) - Climate Change and Biodiversity in the European Union Overseas Entities. 192p., IUCN, Gland, Switzerland / Brussels, Belgium. ISBN: 9782831713151. Available on-line at https://portals.iucn. org/library/efiles/edocs/2010-064.pdf

Phillips, A. (2003a) - Turning ideas on their head - the new paradigm for Protected Areas. The George Wright Forum (ISSN: 0732-4715), 20(2):8-32, Hancock, MI, U.S.A. Available on-line at https://www.uvm.edu/ conservationlectures/turning.pdf

Phillips, A. (2003b) - Un paradigma moderno. Conservación Mundial, 34(2):6-7. Available on-line at http://cmsdata. iucn.org/downloads/vth_iucn_es.pdf

Rietbergen, S.; Hammond, T.; Sayegh, C.; Hesselink F; Mooney, K. (2007) - Island voices - island choices: Developing strategies for living with rapid ecosystem change 
in small islands. 43p., IUCN, Gland, Switzerland. Available on-line at https://portals.iucn.org/library/ efiles/edocs/CEM-006.pdf

Saffache, P.; Angelelli, P. (2010) - Integrated coastal zone management in small islands: A comparative outline of some islands of the Lesser Antilles. Revista de Gestão Costeira Integrada / Journal of Integrated Coastal Zone Management, 10(3):255-279. DOI: 10.5894/rgci228

SCBD (2004) - The Ecosystem Approach - CBD Guidelines. 53p., Secretariat of the Convention on Biological Diversity, Montreal, Canada. ISBN: 929225023x. Available on-line at https://www.cbd.int/doc/ publications/ea-text-en.pdf

SRAM (2008) - Plano de Ordenamento das Bacias Hidrográficas das Lagoas do Caiado, Capitão, Paul, Peixinho e Rosada Fase A - Caracterização/Diagnóstico Prospectivo. Secretaria Regional do Ambiente e do Mar da Região Autónoma dos Açores, Ponta Delgada, Portugal. Unpublished.
SREA (2010) - Séries Estatísticas 1998-2008. Serviço Regional de Estatística dos Açores, Ponta Delgada, Portugal. Available on-line at http://estatistica. azores.gov.pt/Conteudos/Relatorios/lista_relatorios. aspx?idc $=392 \&$ idsc $=2641 \&$ lang_id $=1$

Vieira, C.P. (2007) - Estrutura ecológica em ilhas : o caso de S. Miguel. 116 pp., MSc Thesis, Departamento de Biologia, Universidade dos Açores, Ponta Delgada, Portugal. Available on-line at https://repositorio.uac.pt/ handle/10400.3/303 